\title{
熱いお茶による小巟の喉頭熱傷症例
}

\author{
篠 原宏・清 水啓 成
}

\section{A Case of Thermal Epiglottitis after Swallowing Hot Tea in Child}

\section{Hiroshi Shinohara and Hironari Shimizu}

We herein report a case of thermal epiglottitis in a 4 -year-old boy who swallowed hot tea. The previously healthy patient presented to our outpatient clinic complaining of swallowing pain one day after swallowing hot tea from the spout of a tea pot. On the initial physical examination, he exhibited smalls areas of slight scalding on the tongue and soft palate. Although the damage to the oral cavity was not severe, a fiberscopic examination revealed an erythematous and edematous epiglottis partially covered with a whitish coating. The patient was therefore hospitalized and received treatment with ceftriaxone and predonine. He was able to tolerate soft foods within 24 hours and subsequently discharged from the hospital after 48 hours of observation. A history of swallowing a hot beverage from the spout of kettle or tea pot is an important clue suggesting a thermal burn of the larynx. In order to prevent overlooking a potential diagnosis of thermal epiglottitis, which may cause dyspnea on occasion, the importance of conducting a laryngoscopic examination should be emphasized in patients with a history of any of the following findings: 1) swallowing from the spout of kettle; 2) eating unequally cooled hot foods, the exterior of which is cooled, while the interior is not, such as spring rolls or pastries; 3 ) consuming microwave heated foods or beverages; 4) mental impairment.

Key words : thermal epiglottitis, spout, hot beverage, fiberscopy

\section{は じめに}

熱い飲食物を口内に入れた際に口腔粘膜が障害されるこ とは，日常診療でよく経験されるが，すぐに吐き出してし まうため喉頭にまで障害が及ぶことはまれである。小巟が 急須の注ぎロから熱いお茶を吸い込んで喉頭熱傷に至った 例を経験したので報告する。

$$
\text { 症例 }
$$

4 歳男児 体重 $13.7 \mathrm{~kg}$ 身長 $117 \mathrm{~cm}$ 生来健康 病歴：2013 年 1 月, 夕方, 母親が床からの高さ $80 \mathrm{~cm}$ ほどのテーブルの上にお茶を入れようとして熱湯を入れた ばかりの急須を置いておいた。母親が眼を離した隙に，患 児が注ぎ口からお茶をふざけて吸い込んだ。熱かったた め, すぐ吐き出して泣いた。その後，強い咽頭痛で夕食は 摂取できず，夜間は流涎がみられ 1 時間おきに覚醒してい た。嗄声，呼吸困難はなかった，翌朝，咽頭痛で朝食も摂 取できなかったため当院小巟科受診した。口腔内に白苔で 覆われたびらんが認められ熱傷が示唆され，嚥下痛が強く 下咽頭・喉頭の熱傷も疑われたため当科紹介となった。

初診時所見：体温 $37.4{ }^{\circ} \mathrm{C}$, 全身状態は良好で機嫌もよ かった。呼吸困難や喘鳴など認めなかった。舌尖に直径 $4 \mathrm{~mm}$ ，軟口蓋右側に直径 $10 \mathrm{~mm}$ のびらんを認め熱傷によ るものと考えられたが軽微なものであった（図 1，2）。喉

河北総合病院耳鼻咽喉科

Kawakita General Hospital Dept. Otolaryngology

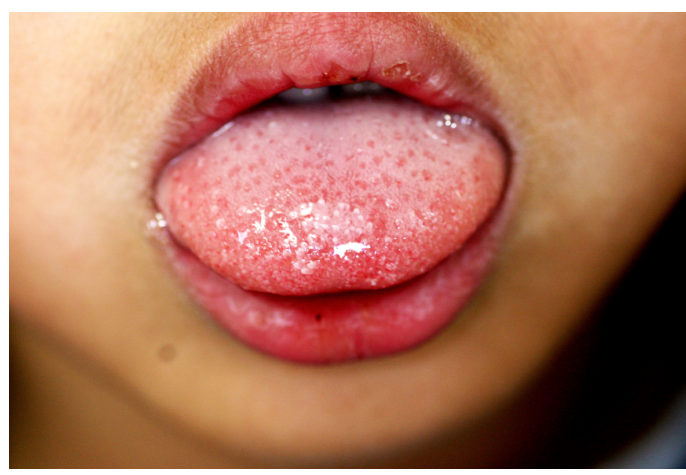

図 1

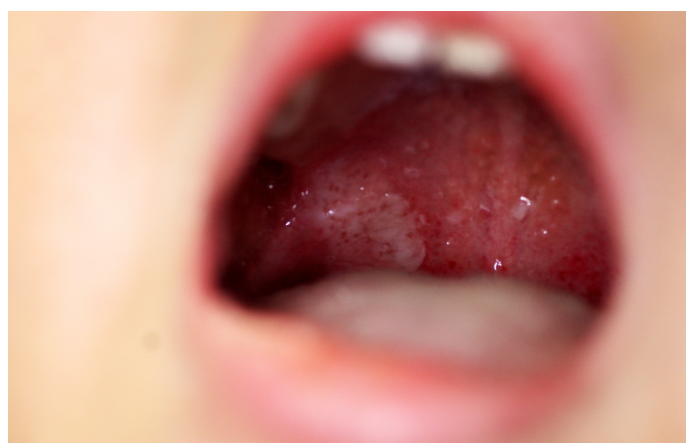

図 2

図 1,2 初診時: 舌尖に直径 $4 \mathrm{~mm}$, 軟口蓋右側 に直径 $10 \mathrm{~mm}$ のびらんを認めた 
頭内視鏡を行ったところ，喉頭蓋から披裂部，咽頭後壁に かけて白苔を伴う喉頭粘膜の発赤と腫脹を認め，喉頭熱傷 と診断した（図 $3 ， 4 ， 5$ ).

治療・経過：呼吸状態, 局所所見から緊急に気道確保が 必要ではないが，気道狭窄に発展する危険があるため入院

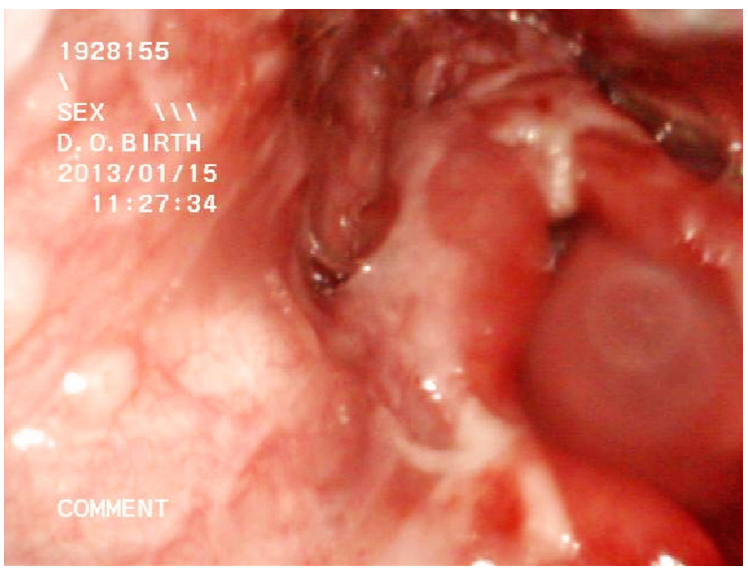

図 3

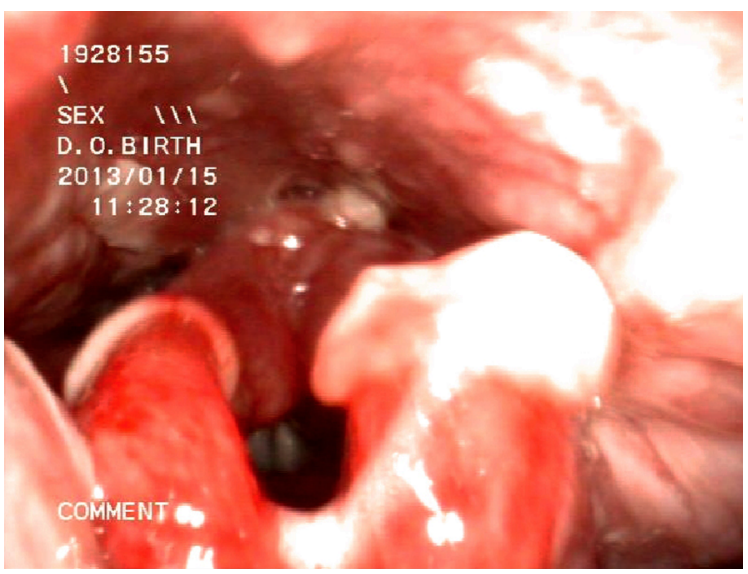

図 4

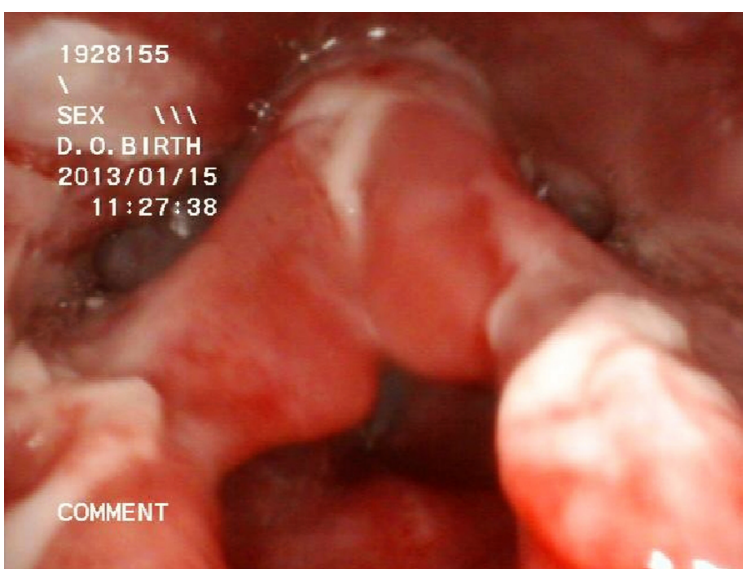

図 5

図 3,4,5 初診時：喉頭蓋から披裂部，咽頭後壁にか けて白苔を伴う喉頭粘膜の発赤と腫脹を認 め、喉頭熱傷と診断した
の上，経過観察を行うことにした。胸部X-Pにて異常を認 めず，喉頭側面X-Pにて喉頭蓋の軽度の腫脹を認めた（図 $6)$. 血液検査ではWBC $16.5 \times 10^{3} / \mu \mathrm{l}, \mathrm{CRP} 2.05 \mathrm{mg} / \mathrm{dl}$ と軽度の炎症反応を示した

入院直後よりプレドニン $20 \mathrm{mg}$ （24 時間ごと）を投与し た。また，セフトリアキソン $600 \mathrm{mg}$ (12 時間ごと) の点 滴投与と補液も開始した。入院翌日より痛みが軽減し，お 籿が摂取できるようになり，入院 3 日目に問題なく食事が 摂取可能となった。同日，喉頭蓋の浮腫の消退を確認し退 院となった（図 7)。退院後の経過は良好で喉頭蓋の変形な どの異常を認めなかった。

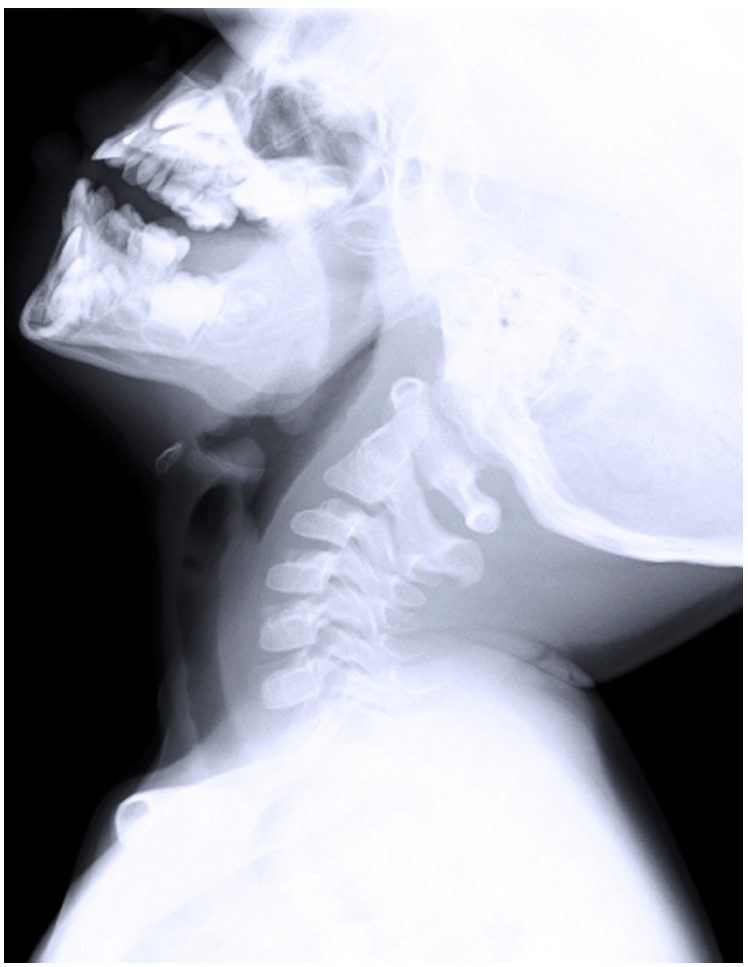

図 6 初診時：喉頭側面X-Pにて喉頭蓋の軽度の腫脹を 認めた

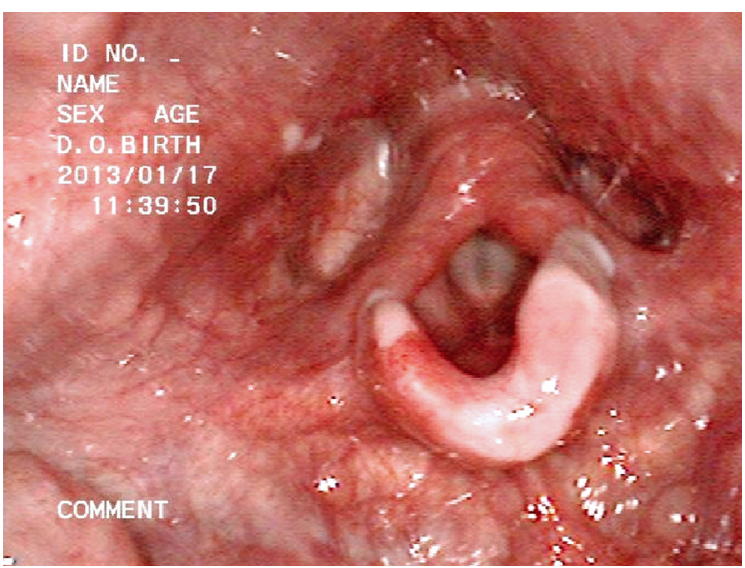

図 7 退院時：喉頭蓋の浮腫は軽快した 


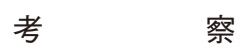

\section{1. 喉頭熱傷の原因}

喉頭熱傷は，火炎，ガス爆発，高温水蒸気の吸引によ る“気道熱傷”の一部として発症する場合と過熱した飲食 物を䁩下する際に生じる“食道熱傷”として生じる場合が あるが ${ }^{1)}$ 前者については本稿では論じない.

通常，われわれが非常に熱いものを口にしたとき，即 座に反射的に吐き出してしまうため熱傷は口腔あるいは 中咽頭に発生するが喉頭に至ることはまれである ${ }^{2 \sim 6)}$ 。し かし，過去の報告から喉頭熱傷をきたすケースは主に以 下の 4 群に大別される。(1)ポットや急須, ヤカンの注ぎ 口から熱湯を吸い込んだ場合（2)外皮，外側は熱くない が内側がとても熱い食物を十分に咀嚼せずに飲み込んだ 場合（たこ焼きや春巻きを飲み込んだ場合）(3)電子レン ジで加熱した食品, 液体 (4)精神疾患・意識障害がある 場合，である。(1) の場合，急須やヤカンの注ぎロから液 体を飲むためには強い陰圧をかけて吸い込むため熱い液 体は速やかに口腔を通過し，下咽頭・喉頭に達してしま う。吐き出すときにはすでに下咽頭・喉頭の熱傷が完成 してしまっていると考えられる。本邦ではかつては畳の 上に火鉢を置きヤカンを載せておいた家庭も多かった。 そのため小児が容易にヤカンに近づくことができヤカン の注ぎロから熱湯を吸い込んだという報告も古くから多 く見られる ${ }^{7 \sim 10)}$ 。 また最近でも国内外問わず小児が急須 やティーポットの注ぎロから吸いこんだという報告があ り ${ }^{11 \sim 13)}$ 小児が急須などの注ぎ口に興味を持っているとい うことを認識する必要がある。

本例のような事故を防ぐためには，急須やヤカン， ティーポットに熱湯を入れた際には親が乳幼児が近付か ないよう注意するような啓蒙が必要と考える。(2)の場合 も日常生活でしばしば経験することである。たこ焼きや 春巻き，小龍包のような食物を食べたとき外皮は冷めて いて口腔内に入れても熱く感じないが，咀嚼して内容物 が口腔内に拡がったときに，その内容物の熱さに驚くこ とはしばしば経験される。このような食物を口腔内で十 分に咀嚼しないで嚥下した場合，食物が下咽頭に至って 崩壊し熱い内容物が外皮を破って逸脱する。このときは じめて熱さに気付くため, 吐き出すには遅すぎ飲み込む しかない窮地に立たされ, 結果, 喉頭熱傷を起こす ${ }^{3,6)}$. (3)電子レンジで加熱した食品は，電子レンジの加熱原理 から水分含有率の高いものがより早く加熱されるため注 意が必要である ${ }^{14)}$ 。電子レンジは周波数 $2.45 \mathrm{GHz}$ の電磁 波が極性分子である水分子を誘電加熱しており ${ }^{15}$, 16) 電子 レンジで陶器のカップに入れた液体を過熱したとき容器 と液体では誘電損失係数が異なるため温度差が生じる ${ }^{17)}$. この原理から，内部に水分の多いものを水分の少ない被 殼で覆うペストリー(クリームなどをパイ生地で包んだお 菓子) のような食品や哺乳瓶に入れたミルクなどで喉頭熱 傷をきたし ${ }^{18 ２ 0)}$ ときに食道熱傷に至る ${ }^{21,22)}$.
また(4)のように精神神経疾患を有する患者や泥酔状態 での喉頭熱傷の報告も少なくない ${ }^{23 \sim 26)}$.

\section{2. 症状・診断}

受傷直後から咽頭痛，とりわけ嚥下時痛がみられる。 熱い飲食物を摂取したという病歴と喉頭を観察すること で診断は比較的容易である。喉頭粘膜の発赤，腫脹，白 苔の付着といった所見があれば確定できる。本症例でも 口腔・咽頭を観察した際は非常にありふれた熱い食物に よる口腔粘膜のびらん程度の所見であったが，食事がで きないということで喉頭を内視鏡で観察してはじめて喉 頭熱傷と診断できた。問診時に前項で挙げた 4 つの群の いずれかに該当するときや疼痛が強いときは，たとえ口 腔・咽頭の熱傷所見が軽微であっても内視鏡による喉頭 の観察が必須であると強調したい.

\section{3. 治療}

入院の上，気道狭窄の危機がないと判断できるまで経 過観察が必要である。気管内挿管を行うべきか否かの基 準は未確立であるが ${ }^{27)}$ 喉頭浮腫は熱傷受傷後 24〜 48 時 間で最も強くなるためその間は厳重な経過観察を要す $3^{27,28)}$ 。喉頭熱傷の治療に定説はないがステロイドと抗 生剂を投与して気道浮腫予防と感染予防を行いながら経 過観察を行った報告が多い2，3，5，6，18，19，20,24, 29 32)．本症例 では初診時の段階で差し迫った気道狭窄の危機はないと 考え入院後にステロイドの点滴静注を行ったが，喉頭蓋 浮腫や喘鳴の程度次第では，外来段階でステロイド静注 や緊急気管切開を適宜行うべきであろう。

\section{4. 予後}

保存的治療，挿管や気管切開といった気道確保が適切 に行われていれば基本的に予後は良好である，少数では あるが，診断が遅れて気道確保のタイミングを逸して訴 訟に発展する例 ${ }^{13)} や ，$ 熱傷によって下咽頭・食道に瘏痕 狭窄が生じたため咽喉頭食道摘出術を余儀なくされた 例 ${ }^{25)}$ も報告されており注意する必要がある。

\section{ま と め}

熱い飲食物による口腔熱傷は日常よく遭遇する疾患で ある。しかしその中に喉頭熱傷をきたしているものがあ り，その見極めは非常に重要で，ときとして重大な結果 を招く可能性がある。臨床の現場では，問診の段階で (1) ポットや急須，ヤカンの注ぎロから熱湯を吸い込んだ場 合 (2)外皮，外側は厚くないが内側がとても熱い食物を 十分に咀嚼せずに飲み込んだ場合（たこ焼きや春巻きを飲 み込んだ場合）（3)電子レンジで加熱した食品，液体を捸 取した場合(4)精神疾患・意識障害，がある場合，がある と判明したら口腔内の熱傷所見が非常に軽微であったと しても喉頭を注意深く観察すべきである. 


\section{謝辞}

当院小児科, 足立 浩先生に深謝します.

本論文の要旨は第 26 回日本喉頭科学会総会・学術講演 会 (那覇市) で発表した。

利益相反：該当事項なし

\section{文献}

1）二藤隆春：【耳鼻咽喉科の外傷に強くなる】喉頭熱 傷. JOHNS 25：1375-1378, 2009.

2) Kulick RM, Selbst SM, Baker MD et al : Thermal epiglottitis after swallowing hot beverages. Pediatrics 81 : 441-444, 1988.

3）本田圭司, 鎌田知子, 田崎彰久ほか：緊急気道確保を要 したたこ焼きによる咽喉頭熱傷例。耳鼻臨床 105 ： 681-685, 2012.

4) Harjacek M, Kornberg AE, Yates EW et al : Thermal epiglottitis after swallowing hot tea. Pediatric Emergency Care 8 : 342-344, 1992.

5) Goto R, Miyabe K, Mori N : Thermal burn of the pharynx and larynx after swallowing hot milk. Auris Nasus Larynx 29 : 301-303, 2002.

6) Shenoy VN, Chandrashekar KB, Pai S : Acute thermal ulceration of the epiglottis. J of Mississippi State Med Association 50 : 259-261, 2009.

7) 出光計一：幼児熱湯誤曣二就イテ. 耳鼻咽喉科 10 : 1047-1051, 1937.

8）富澤春雄：幼児熱湯誤嚥ノ一治験例。耳鼻咽喉科 10 : 1052-1054, 1937.

9）古川林三郎：熱湯誤燕ニヨル咽喉頭火傷ノ一治験例. 耳鼻咽喉科 $10: 1055-1059,1937$.

10）頭司忠雄, 中嶋卓磨：熱湯誤嚥に因る幼児の咽喉頭湯 傷例に就て。耳鼻臨床 $37: 318-322,1942$.

11）横路征太郎：喉頭熱傷と緊急気管内挿管. 東京小児科 医会報 $15: 50-56,1997$.

12) Dye DJ, Milling MAP, Emmanuel ER et al : Toddlers, teapots, and kettles: beware intraoral scalds. Br Med J $300:$ 597-598, 1990.

13) Brahams D : Respiratory failure in a young child after aspiration of hot tea. Anesthesia 44:858-859, 1989.

14) Sando WC, Gallaher KJ, Rodgers BM : Risk factors for microwave scald injuries in infants. J of Pediatr $105: 864-867,1984$.

15）トーレン出版部：科学者からのメッセージ 電子レン ジ 11-14, トーレン出版部, 1985 .

16）理科教育研究会：電気の図鑑 118-119, 技術評論
社, 東京, 2013 .

17）肥後温子：新版 電子レンジ「こつ」の科学 30-31, 柴田書店, 東京, 2005.

18) Garland JS, Rice TB, Kelly KJ : Airway burns in an infant following aspiration of microwave-heated tea. Chest $90: 621-622,1986$.

19）江口博之,菅谷明則, 高橋弘剛ほか：喉頭熱傷：熱い食 事摂取が原因の 1 男児例. 日小児呼吸器会誌 $7: 102-$ 106, 1996.

20）王子佳澄, 冨永 健：喉頭熱傷により緊急気管切開を 要した 1 例. 耳鼻臨床 補 $120: 72,2007$.

21) Perlman A : Hazards of a microwave oven. N Engl J Med 302: 970-971, 1980.

22) Lieberman DA, Keeffe EB : Esophageal burn and the microwave oven. Ann Intern Med 97 : 137, 1982.

23) Kornak JM, Freije JE, Campbell BH : Caustic and thermal epiglottitis in the adult. Otolaryngol Head and Neck Surg $114: 310-312,1996$.

24) Ma OJ, Phelan MB : Adult thermal epiglottis. Ann of Emergency Med $27: 675,1996$.

25 ）兵頭政光, 森 敏裕, 宮本佳人：過熱アルコールによ る咽喉頭 - 食道の高度熱傷症例. JOHNS 17：17711773, 2001.

26）井上典子, 矢守麻奈, 塩谷由美子ほか：咽喉頭熱傷に より嚥下障害をきたした統合失調症の 1 例。言語聴覚 研究 $6: 77-82,2009$.

27）井上卓也, 杉木大輔, 池上敬一ほか：喉頭損傷型気道 熱傷に対する気管挿管適応基準，日救急医会誌 19： 262-271, 2008.

28）横山秀二, 大森孝一：【頭頸部領域の温度外傷 - 化学 的腐食の取り扱い】喉頭 ·下咽頭. 耳喉頭頸 79: $35-40,2007$.

29）須藤 敏, 與座朝義, 大田重人ほか：誤飲により喉頭 浮腫を来たした 2 症例 -アルカリ洗剤, 熱いミルク-. 小児耳 $26: 55-59,2005$.

30）東川雅彦：【頭頸部領域の温度外傷·化学的腐食の取 り扱い口腔 - 咽頭の温度外傷. 耳喉頭頸 79:2328, 2007.

31) Lai SH, Wong KS, Liao SL et al : Non-infectious epiglottitis in children two case report. Int. J. Pediatr. Otorhinolaryngol 55 : 57-60, 2000.

32) Alpay HC, Kaygusuz I, Karlidag T et al : Thermal burn of the larynx in an adult following hot water aspiration. Otolaryngol Head and Neck Surg 139 : 164$165,2008$.

別刷請求先 $\overline{\mathrm{T}}$ 166-0001 東京都杉並区阿佐谷北 1-7-3 河北総合病院耳鼻咽喉科篠原 宏 